\title{
What Was to Happen Already Occurred
}

On the sidewalk, petals from Bradford pear trees scattered at her approach.

She carried a blue notebook. Her hair was down. She walked among the stones crowding the grass

like the pears in my grandparents' yard.

She frowned, her dark eyes like my grandfather's

when he glared across the yard, slouched, peeling a fallen pear.

"Where are you from, Harold?" she said, doing her best Brando.

My fingers rested on my empty cup's rim.

After her coffee came, we could not stop talking,

our words decrees of nullity.

We left off at my grandfather's last question

as we left the nursing home:

"Why do they have to tie me up?"

We had no answers. We lied.

The waiter took our cups. "I know, I know," I said.

"I know I'm fine without you."

Evening shadows edged up the red brick wall.

She drummed on the table and looked away.

Bus fumes ratified our goodbyes.

Later, at her request, I sat

in her apartment waiting,

the made bed a remnant of her touch.

140 